\title{
Abnormal Cervical Cytology Risk Factors in the Western Black Sea Region and the Importance of Health Insurance
}

\section{Batı Karadeniz Bölgesinde Anormal Servikal Sitoloji Risk Faktörleri ve Sağlık Sigortasının Önemi}

\author{
Serap SIMAVLI ${ }^{1,2}$, İkbal KAYGUSUZ ${ }^{3}$, Selma ÇUKUR ${ }^{4}$, Ferda AKSEL ${ }^{4}$ \\ Department of Obstetric and Gynecology, ${ }^{1}$ Pamukkale University, Faculty of Medicine, DENIZLI, TURKEY and \\ ${ }^{3}$ Turgut Özal University, Faculty of Medicine, ANKARA, TURKEY, \\ ${ }^{2}$ Laboratory of Reproductif Endocrinology, Brigham and Women's Hospital , Harvard Medical School, Boston, MA, USA, \\ ${ }^{4}$ Department of Pathology, Bolu Izzet Baysal State Hospital, BOLU, TURKEY
}

\begin{abstract}
Objective: To evaluate the prevalence of abnormal cervical cytological findings in the Western Black Sea Region and investigate an association between socio-demographic risk factors and the presence of cytological abnormalities.
\end{abstract}

Material and Method: The reports of 11,539 cervical smears diagnosed according to Bethesda System 2001 version in the Pathology Department between January 2011 and December 2012 were reviewed retrospectively from the hospital records and cytopathology reports. Repeated smear results, unsatisfactory smear results, patients with known gynecologic malignancy history, smear results of patients with hysterectomy and smear results of patients whose socio-demographic information could not be obtained were excluded from the evaluation. The results of 7,740 patients who met the criteria for the study were evaluated.

Results: The prevalence of cervical cytological abnormalities was $1.8 \%$ in general. The prevalence rates for atypical squamous cells with undetermined significance (ASC-US), atypical squamous cells, cannot exclude a high-grade squamous intraepithelial lesion (ASC-H), low-grade squamous intraepithelial lesions (LSIL), high-grade squamous intraepithelial lesions (HSIL), and atypical glandular cells (AGC) were $1.16 \%, 0.11 \%, 0.29 \%, 0.15 \%$, and $0.03 \%$ respectively. The prevalence of cytologically diagnosed cervical invasive neoplasia was $0.025 \%$. Advanced age, low education level (primary school or less) and not having health insurance were found as to be risk factors for preinvasive and invasive lesions. Women who had a high school education and previously had a smear test had decreased risk for developing preinvasive and invasive lesions.

Conclusion: This study shows prevalence of abnormal cervical cytology findings and associoted risk factors in the Western Black Sea Region of Turkey. The most important risk factor was identified as not having health insurance.

Key Words: Vaginal smears, Uterine cervical neoplasms, Risk factors, Health insurance, Turkey

(Turk Patoloji Derg 2014, 30:11-17)

Received : 30.06.2013 Accepted : 03.09.2013
ÖZ

Amaç: Batı Karadeniz bölgesinde anormal servikal sitoloj prevelansının değerlendirilmesi ve sosyo-demografik risk faktörleri ile anormal sitoloji varlığının ilişkisinin araştırılması.

Gereç ve Yöntem: Ocak 2011-Aralık 2012 tarihleri arasında patoloji bölümüne gönderilen ve Bethesda Sistemi 2001 versiyonuna göre tanı alan toplam 11,539 servikal smear örneğine ait raporlar hastane kayitlarından ve patoloji raporlarından retrospektif olarak incelendi. Aynı hasta için yinelenen smearler, yetersiz smear sonuçları, bilinen jinekolojik malignitesi olan hastalar, histerektomize hastaların smear sonuçları ile sosyo-demografik verilerine ulaşılamayan hastalar değerlendirilme dışı bırakıldı. Çalışma kriterlerini karşılayan 7,740 olgunun sonuçları değerlendirildi.

Bulgular: Toplam sitolojik anormallik prevelansı \%1.8, önemi belirlenemeyen atipik skuamöz hücreler (ASC-US), yüksek dereceli skuamöz intraepitelyal lezyon ekarte edilemeyen atipik skuamöz hücreler (ASC-H), düşük dereceli skuamöz intraepitelyal lezyon (LSIL), yüksek dereceli skuamöz intraepitelyal lezyon (HSIL) ve atipik glandüler hücre (AGC) prevelansları sırası ile \%1.16, \%0.11, $\% 0.29, \% 0.15$ ve $\% 0.03$ olarak bulundu. Sitolojik olarak belirlenen servikal invaziv kanser prevelansı \%0.025 tespit edildi. İleri yaş, düşük eğitim düzeyi (ilkokul ve altı) ve sağlık sigortasına sahip olmamanın preinvaziv ve invaziv lezyon riskini arttırdığı, lise mezunu olma ve daha önce smear testi yaptırmış olmanın ise preinvaziv ve invaziv lezyon riskini azalttığı tespit edildi.

Sonuç: Bu çalışmada, Türkiye'nin Batı Karadeniz bölgesinde anormal smear sonucu bulguları ve birlikte olabilecek risk faktörleri belirlendi. Hastanın sağlık sigortasının olmaması, en önemli risk faktörü olarak tespit edildi.

Anahtar Sözcükler: Vajinal yaymalar, Uterin servikal neoplazi, Risk faktörleri, Sağlık sigortası, Türkiye

Correspondence: Serap SIMAVLI

Pamukkale Üniversitesi, Tip Fakültesi, Kadın Doğum Anabilim Dalı, DENIZLII, TURKEY

E-mail: serapsimavli@yahoo.com Phone: +90 2584440728 


\section{INTRODUCTION}

Cervical cancer is the third most common cancer in women worldwide after breast cancer and colorectal cancer and it is the most common cancer in less developed countries such as East Africa and South-Central Asia. It is a cause of significant morbidity and mortality especially at younger ages and in developing countries (1). Approximately 400,000 to 550,000 new cervical cancer cases are seen worldwide each year, 190.000 to 275.000 of these cases result in death and $85 \%$ of the deaths are seen in developing countries $(1,2)$.

According to the results of the study performed by the Ministry of Health Department of Cancer in 8 provinces that are thought to represent Turkey, cervical cancer is 10th among cancers that affect Turkish women with an incidence of 4.76/100,000 (3).

The Papanicolaou (Pap) smear is a simple, convenient, noninvasive, and inexpensive test widely used for cervical cancer screening in many countries. Pap smear was introduced to the medical world for the first time by Dr. George Papanicolaou and has been recommended by the American Cancer Society as a screening test in 1945. It has led to a dramatic reduction in the prevalence of cervical cancer and mortality rates with early diagnosis of preinvasive lesions (2).

The most widely used and accepted classification for reporting cervical smear samples is the Bethesda System 2001 version (4). The applied screening frequency and the age screening begins differ between countries according to the target population, the country's financial conditions and the incidence of cervical cancer. It is recommended that screening be started at the age of 35 , and discontinued at the age of 65 to be repeated every five years in Cancer Early Diagnosis, Screening and Training Center (KETEM) units in Turkey.

The start of the national screening program in our country in 2008 and its spread in time will make the determination of the prevalence of cervical lesions possible in the future. It is difficult to predict the prevalence and incidence of the pre-invasive and invasive cervical lesions and to determine their risk factors at present. The aim of the study was to determine the diagnosis distribution in cervical smear samples examined in our hospital and evaluate whether there was a difference in the sociodemographic features of the groups with a normal and abnormal smear result to specify the risk factors.

\section{MATERIAL and METHOD}

11,539 cervical smears examined between January 2011 and December 2012 at the Pathology Department of our hospital were evaluated for our study group. Patient information was retrospectively screened from hospital records, family planning records and pathology archives. The smear results of patients who had undergone hysterectomy, the smears repeated for the same patient, inadequate smears, those with a known history of gynecological malignancy and the results of those whose socio-demographic information (age, marital status, number of pregnancies, number of births, educational status, contraceptive use, health insurance and whether the patient had undergone a smear test before) could not be found were excluded from the study. Data on whether the patients had undergone a smear test before was found from the pathology records of the last 5 years in our hospital or from patient charts for those cases where the test was done at an external center and the result recorded in the chart. The study group consisted of the cervical smears of the patients coming from three provinces, distributed as $65 \%$ from Bolu, 25\% from Düzce and 10\% from Zonguldak.

All cervical smears evaluated in our study were obtained with a brom-like brush (Medbar •, Code: JIN-22) and spread on a slide, fixed with spraying from a distance of 25$30 \mathrm{~cm}$, and sent to the pathology laboratory of our hospital for examination. All smears were evaluated with three pathologists in the Pathology Department according to the Bethesda System 2001 diagnostic terminology. Cases with abnormal epithelial and glandular cells formed the study group while cases without a pre-invasive or invasive lesion (normal cases, cases with infection findings, and cases where regeneration atypia was observed) constituted the control group.

\section{Statistical Analyses}

All the data in the study were digitized and checks were performed against incorrect data entries. The Microsoft Excel and SPSS for Windows ver. 16:00 (SPSS Inc., IL. USA) software packages were used for statistical analysis. Continuous variables were first inspected for normality of statistical distribution graphically and by Shapiro-Wilk test. When descriptive statistics were given, Mean \pm Standard Deviation (SD) or Median (interquartile range [IQR]) was used for measured variables and numbers and percentages for coded (categorical) variables. The chi-square test was used to compare categorical variables, and the Student's $\mathrm{t}$ test and Mann-Whitney $\mathrm{U}$ test to compare continuous data. Risk factors that may be associated with pre-invasive and invasive lesions were evaluated by logistic regression 
analysis. The following materials were included in the model: age, number of pregnancies, number of births, education level, marital status, contraceptive methods, lack of health insurance and not having had a smear test previously. Results were evaluated with a 95\% confidence interval and significance level of $p \leq 0.05$.

\section{RESULTS}

Of the 11,539 cases with Pap smear results, the smears of 7,740 patients that met the study criteria were evaluated. The ages of the patients varied between 19 and 69 years. The inadequate smear rate was $1.24 \%$ ( 144 cases) and these cases were excluded from the study. Causes of inadequate smears were reported as infection, bleeding, and an insufficient number of cells. 139 women with abnormal smear result formed the study group and 7,601 women without a lesion formed the control group. The 5,429 cases making up the control group did not show any infection or regeneration atypia findings. When the smear tests of 1,346 cases with an infection were evaluated, nonspecific inflammation was found in 1,254 cases, candidiasis in 42 patients, coccobacillus in 38 patients, and actinomyces infection in 12 cases. An IUD was present in all patients with actinomyces.

A preinvasive lesion was found according to the Bethesda System 2001 version in $137(1.77 \%)$ cases and invasive cancer in 2 cases. The prevalence distribution was ASC-US $1.16 \%$, ASC-H 0.11\%, LSIL 0.29\%, HSIL 0.15\%, AGC 0.03\% and invasive cancer $0.025 \%$ (Table I). When the abnormal smear results were examined, $90(64.74 \%)$ cases were ASCUS, 9 (6.47\%) ASC-H, 23 (16.54\%) LSIL, 12 (8.63\%) HSIL, $3(2.15 \%)$ AGC and $2(1.43 \%)$ invasive cancer.

The distribution and characteristics of the groups in the study are presented in Table II. There was a statistically significant difference between the ages of the women with and without a lesion $(\mathrm{p}<0.001)$. The number of pregnancies and births were similar between the groups $(p=0.93$ and $\mathrm{p}=0.51$ respectively). When the educational status was evaluated, the group with a cervical lesion was found to have a higher number of women who were graduates of a primary school or less and a smaller number of women who were graduates of high school and these conditions were found to be statistically significant ( $\mathrm{p}<0.001 ; \mathrm{p}=0.03$ respectively). Although the percentage of university graduates was lower in the group with a lesion, no statistically significant difference was found. No statistically significant difference was found in terms of marital status as regards the incidence of cervical lesions ( $p>0.05)$. When the use of contraceptive methods was evaluated, cervical lesions were found to be more frequent in those who did not use any method and less in those whose partners were condom users, but there was no statistically significant difference ( $\mathrm{p}>0.05)$. Rate of having a smear done previously was $43.9 \%$ in cases with a lesion and $52.8 \%$ in those without, and this difference was statistically significant $(\mathrm{p}=0.04)$. Similarly, the rate of the absence of health insurance was $15.8 \%$ in the group with a lesion and $1.9 \%$ in the group without a lesion. This difference between the groups was found to be statistically significant $(\mathrm{p}<0.001)$.

The factors of age, number of pregnancies, number of births, education level, marital status, contraceptive methods, health insurance and having a smear done previously, which are considered to have an effect on the development of preinvasive and invasive lesions, were analyzed with logistic regression analysis. As a result of logistic regression analysis in a total of three steps, it was found that the factors of age, education level of primary school or less, having graduated from high school, lack of health insurance, and having undergone smear testing before had a significant effect on the development of pre-invasive and invasive lesions. Advanced age was found to increase the risk of cervical lesion development 1.047 times (95\% CI, 1.029-1.065), low level of education (primary school or less) 3.336 times (95\% CI, 1.299-8.570), and lack of health insurance 34 times (95\% CI, 15.252-75.887), whereas being a graduate of high school was found to decrease the risk 0.084 times (95\% CI, $0.031-0.228$ ), and having had a smear test previously 0.347 times (95\% CI, 0.184-0.655) (Table III).

Table I: The distribution of Pap smear results

\begin{tabular}{|l|r|c|}
\hline & Number & (\%) \\
\hline Infection & 1,346 & 17.39 \\
\hline Reactive changes & 826 & 10.67 \\
\hline Normal & 5,429 & 70.14 \\
\hline Pre-invasive lesions & 137 & 1.77 \\
\hline ASC-US & 90 & 1.16 \\
\hline \multicolumn{1}{|c|}{ ASC-H } & 9 & 0.11 \\
\hline LSIL & 23 & 0.29 \\
\hline HSIL & 12 & 0.15 \\
\hline AGC & 3 & 0.03 \\
\hline Invasive cervical cancer & 2 & 0.025 \\
\hline Total & 7,740 & 100 \\
\hline
\end{tabular}

ASC-US: Atypical squamous cells with undetermined significance, ASC-H: Atypical squamous cells, cannot exclude a high-grade squamous intraepithelial lesion, LSIL: Low-grade squamous intraepithelial lesion, HSIL: High-grade squamous intraepithelial lesion, AGC: Atypical glandular cell. 


\section{DISCUSSION}

Determination of the risk factors of cervical cancer, the most common gynecological cancer, and its early diagnosis are very important in terms of obtaining a cure. The most important risk factor for a cervical lesion was found to be the lack of health insurance in our study. Although cervical cancer can be determined in the pre-invasive period with Pap smear screening and treated, it still continues to be a major health problem globally and especially in developing countries. Dramatic reductions have been seen in cervical cancer incidence and cancer mortality rates in developed countries with a national screening program. The incidence of cervical cancer in developing countries is still very high due to the lack of effective screening programs where preinvasive lesions can be determined and treated without turning into invasive cancer, in line with the country's low economic status. Societies with a low socio-economic level usually have low percentages of the population covered by health insurance. If the country does not have a free national screening program, the rate of undergoing screening in the individuals without health insurance is very low and accordingly the rate of cervical lesions is very high. Our

Table II: Distribution of risk factors according to the groups

\begin{tabular}{|c|c|c|c|}
\hline Variables & Those with a lesion $(n=139)$ & Control group $(n=7601)$ & $\mathbf{p}$ \\
\hline Age $($ Mean \pm SD $)$ & $41.15 \pm 11.44$ & $36.17 \pm 9.20$ & $<0.001$ \\
\hline Pregnancy (Median [IQR] ) & $3.00(1.00)$ & $3.00(1.00)$ & 0.93 \\
\hline Birth (Median [IQR] ) & $3.00(2.00)$ & $3.00(2.00)$ & 0.51 \\
\hline \multicolumn{4}{|l|}{ Educational status } \\
\hline Primary school or less & $75.5 \%{ }^{\star}$ & $61.6 \%^{*}$ & 0.04 \\
\hline High school & $11.5 \% \%^{\star *}$ & $19 \%^{* *}$ & \\
\hline University & $12.90 \%$ & $19.30 \%$ & \\
\hline \multicolumn{4}{|l|}{ Marital status } \\
\hline Married & $93.50 \%$ & $94.10 \%$ & 0.71 \\
\hline Previously married & $5.00 \%$ & $5.10 \%$ & \\
\hline Single & $1.40 \%$ & $0.80 \%$ & \\
\hline \multicolumn{4}{|l|}{ Contraceptive method } \\
\hline Does not use & $22.30 \%$ & $21.20 \%$ & 1 \\
\hline Condoms & $15.80 \%$ & $17.60 \%$ & \\
\hline Intrauterine device & $23.74 \%$ & $23.10 \%$ & \\
\hline Hormonal contraception & $12.20 \%$ & $12.00 \%$ & \\
\hline Tubal Ligation & $3.60 \%$ & $3.40 \%$ & \\
\hline Traditional methods & $22.30 \%$ & $22.90 \%$ & \\
\hline Having a smear done & $43.90 \%$ & $52.80 \%$ & 0.04 \\
\hline Does not have health insurance & $15.80 \%$ & $1.90 \%$ & $<0.001$ \\
\hline
\end{tabular}

Values were given as Mean \pm Standard Deviation (SD), median (Interquartile range [IQR]) or percentages. The chi-square test for categorical data, Student's $t$ test and the Mann-Whitney U test for continuous data were used to evaluate the difference between the groups. ${ }^{*} ; \mathrm{P}<0.001,{ }^{* *} ; \mathrm{P}=0.03$.

Table III: The logistic regression analysis of factors associated with pre-invasive and invasive lesions

\begin{tabular}{|l|c|c|c|c|c|c|}
\hline & Regression & \multirow{2}{*}{$\begin{array}{c}\text { Standard } \\
\text { Coefficient }\end{array}$} & \multirow{2}{*}{$\mathbf{p}$} & \multirow{2}{*}{ Odds Ratio } & \multicolumn{2}{|c|}{ 95\% Confidence interval } \\
\cline { 5 - 7 } & 0.046 & 0.009 & $<0.001$ & 1.047 & Lower & Upper \\
\hline Age & 1.205 & 0.481 & 0.01 & 3.336 & 1.299 & 1.065 \\
\hline Primary school or less & -2.474 & 0.508 & $<0.001$ & 0.084 & 0.031 & 0.228 \\
\hline High school & 3.527 & 0.409 & $<0.001$ & 34.021 & 15.252 & 75.887 \\
\hline No health insurance & -1.057 & 0.324 & 0.001 & 0.347 & 0.184 & 0.655 \\
\hline Having a smear done & &
\end{tabular}


study has also found that the lack of health insurance increased the risk of cervical lesion development 34 times.

While only $5 \%$ of women undergo a screening test in developing countries, this rate increases to about $90 \%$ in developed countries (5). The Pap smear implementation rate of various countries have been reported as $93 \%$ for the USA (6), $69 \%$ for Spain (7), and 20\% for Kenya (8). Studies conducted in Turkey report rates between $16.2 \%$ (9) and $51.32 \%(10)$. The rate of having a smear done in our study was $52.65 \%$ (43.9\% in the group with a lesion, $52.8 \%$ in the control group).

Regional differences can be present in the incidence of cervical lesions and cervical cancer in our country as all as over the world. Total abnormal cytology was found in $1.8 \%$, ASC-US prevalence in $1.07 \%$, LSIL in $0.3 \%$ and HSIL in $0.17 \%$ in the study with 140,334 patients conducted by Turkish Cervical Cancer and Cervical Cytology Research Group in 33 centers (11). The cytological abnormality prevalence was $2.8 \%$ in a study by Atilgan et al (12) where 32,026 smear results were evaluated. The pathology distribution was ASC-US $1.9 \%$, ASC-H $0.1 \%$, AGS $0.2 \%$, LSIL $0.5 \%$, and HSIL $0.1 \%$ with cervical squamous carcinoma in 3 cases. Cytological abnormality was found to be $6.2 \%$ and invasive cancer prevalence to be $0.6 \%$ in the study conducted by Özgün et al (13) in the province of Mardin. The prevalence of pre-invasive and invasive lesions in the province of Mardin was higher than in other regions of the country. The prevalence of a pre-invasive lesion in our study was $1.77 \%$ and the prevalence of cervical cancer was $0.025 \%$. These results show that the incidence of cervical cancer in Turkey is less than in many other countries that have an advanced national screening program and carry out these programs on a regular basis. Sociocultural factors, traditional lifestyle, religious beliefs and the low prevalence of HPV are possible factors.

Most women were shown not to know the importance of the Pap smear test and the risk factors for cervical cancer in studies performed $(9,14-16)$. Not having information on the smear test and risk factors can prevent the appropriate use of early diagnosis and treatment methods $(9,17,18)$.

The first risk factor determined for cervical cancer was the number of births, with increased relative cervical cancer risk with increased number of births. Cervical cancer was found to increase with the number of pregnancies and births, with a number over three and first pregnancy and birth at an early age being important risk factors (19-21). The number of pregnancies and births were similar between the groups in our study ( $\mathrm{p}=0.93$ and $\mathrm{p}=0.51$ respectively). The number of pregnancies and births were not identified as risk factors. The number of births does not usually exceed 2 in our region and this seems to be a factor. The number of births was more than four in both patients with cervical cancer.

The use of hormonal contraception (combined oral contraceptive pills and injection forms) is one of the risk factors for cervical cancer. Those using hormonal contraception for 5 years or more were found to have more cervical dysplasia than those who have not used such contraception in the literature (22-24). The use of hormonal contraception in the group with and without lesions was similar in our study. Logistic regression analysis revealed that the use of a hormonal contraceptive method was not a risk factor.

The most important factor in the etiology of cervical cancer is human papilloma virus (HPV) $(25,26)$. HPV is a sexually transmitted infectious agent that is detected in $99 \%$ of the cervical pre-invasive and invasive lesions. Starting sexual intercourse at an early age, unprotected intercourse, the subject or the partner having multiple sexual partners, the presence of sexually transmitted infections or a history of infection in the subject or the partner are important risk factors for HPV infection and cervical cancer (20,27-29) and using a condom protects against sexually-transmitted diseases and cervical cancer. The rate of condom use in spouses of the women was higher for the group without a lesion but not statistically significant $(17.60 \%$ versus $15.82 \%)$.

The relationship between IUD use and cervical cancer is not clear. Some studies report that cervical cancer risk does not change with the use of IUD (30), while others have found a decreased risk $(31,32)$. The use of an IUD was similar in the two groups in our study.

Low socio-economic status, low educational level, and lack of health insurance are among the risk factors for cervical cancer. These factors were found to be associated with not undergoing screening (33-43). Olesan et al (35) where they investigated the factors affecting having a cervical smear done in 1,685 women in their cross-sectional study and reported that the target population should be the individuals who are alone, not working, with low income, and do not use health services or use them infrequently. Sabates et al (41) reported in their study that the most important parameter affecting the smear test use is the level of education. Both our patients with cervical cancer was found to have a low level of education, had not undergone screening previously and one did not have health insurance. Being a graduate of high school reduced the risk of cervical lesions while an 
education status of primary school or less increased the risk. This result is consistent with the literature. All studies investigating risk factors have reported low educational level (primary school or less) as a risk factor, while an increase in the level of education and especially being a high school graduate (22) is protective. Being a graduate of secondary or high school was found to be a protective factor in our study. Although the percentage of university graduates was lower in the group with lesion, we found no effect of being a university graduate on risk reduction in the regression analysis.

The most striking result of our study is the determination that the lack of health insurance increased the risk of cervical lesion development 34 times. Nelson et al (36) found a close relationship between regular smear tests and the presence of health insurance. The rate of undergoing a smear test previously in women without health insurance was found to be $8.3 \%$ in our study. We direct the women who do not have health insurance and cannot undergo a smear test at our hospital due to financial reasons to the KETEM unit after explaining the importance of smears. Based on our experience, we can say that most women do not know that smear tests are done without charge at KETEM units and public awareness needs to be created in this matter.

Shanta et al (43) concluded that cervical cancer mortality and morbidity can be reduced with increasing the educational level, screening of the high risk group and development of socioeconomic conditions in their study where they investigated the risk factors for cervical cancer. The literature reports education, socioeconomic status, and sexual behavior pattern as the most important factors for cervical cancer. Jennings-Dozier and Lawrence (22) found being a graduate of high school and having health insurance to be the most important parameters affecting the rate of undergoing an annual Pap smear. Subjects with low educational level and without health insurance were reported to constitute the high-risk group that should especially undergo screening. Only a few studies investigating the risk factors for cervical lesions have evaluated health insurance as a separate parameter and they have found it to be a risk factor. However, the result of our study shows that the lack of health insurance is the most important risk factor, especially in the Western Black Sea Region. It should be investigated as a separate risk factor parameter in future studies.

Although there are many health behaviors that can reduce the risk of cervical cancer, none is as effective and important as a routine Pap smear test (22). The age, marital status, education level, income level, health insurance status, cost, lack of access to diagnosis and treatment opportunities, and cultural characteristics of women are effective in having a Pap smear done (22,34-43). The patients with a lesion in our study had undergone a smear test at lower rates. Only $17 \%$ of those with an educational level of primary school or less had undergone a smear test previously and neither cervical cancer cases had a previous smear test. We found that undergoing a smear test previously reduced the risk of cervical lesion (OR: 0.347, 95\% CI 0.18-0.65).

In conclusion, cervical cancer prevention requires protection from the risk factors that may cause cervical cancer and most importantly routinely undergoing Pap smear tests. While the lack of health insurance was identified as the most important risk factor in our study, we found that advanced age and an educational level of primary school or less increased the cervical lesion risk while being a graduate of high school and having undergone a smear test before decreased the cervical lesion risk.

\section{REFERENCES}

1. Ferlay J, Shin HR, Bray F, Forman D, Mathers C, Parkin DM. Estimates of worldwide burden of cancer in 2008: GLOBOCAN 2008. Int J Cancer. 2010;127: 2893-2917.

2. Parkin DM, Bray F, Ferlay J, Pisani P. Global cancer statistics, 2002. CA Cancer J Clin. 2005;55: 74-108.

3. Yilmaz HH, Yazihan N, Tunca D, Sevinc A, Olcayto EO, Ozgul N, Tuncer M. Cancer trends and incidence and mortality patterns in Turkey. Jpn J Clin Oncol. 2011; 41:10-6.

4. Solomon D, Davey D, Kurman R, Moriarty A, O'Connor D, Prey M, Raab S, Sherman M, Wilbur D, Wright T Jr., Young N, Forum Group Members. The 2001 Bethesda System: Terminology for reporting results of cervical cytology. JAMA. 2002;287: 2114-19.

5. Kuo DY, Goldberg GL. Screening of cervical cancer: where do we go from here? Cancer Invest. 2003; 21: 157-61.

6. Sirovich BE, Welch HG. The frequency of Pap smear screening in the United States. J Gen Intern Med. 2004;19:243-50.

7. Byrd TL, Peterson SK, Chavez R, Heckert A. Cervical cancer screening beliefs among young Hispanic women. Prev Med. 2004;38:192-7.

8. Gichangi P, Estambale B, Bwayo J, Rogo K, Ojwang S, Opiyo A, Temmerman M. Knowledge and practice about cervical cancer and Pap smear testing among patients at Kenyatta National Hospital, Nairobi, Kenya. Int J Gynecol Cancer. 2003;13: 827-33.

9. Karaca M, Palancı Y, Aksu SR. Pap smear ne kadar biliniyor, ne kadar uygulanıyor? Türkiye Klinikleri J Gynecol Obst. 2008;18:22-8.

10. Akyüz A, Güvenç G, Yavan T. Evaluation of the Pap smear test status of women and of the factors affecting this status. Gülhane Med J. 2006;48:25-9.

11. Turkish Cervical Cancer and Cervical Cytology Research Group. Prevalence of cervical cytological abnormalities in Turkey. Int J Gynaecol Obstet. 2009;106:206-9.

12. Atilgan R, Celik A, Boztosun A, Ilter E, Yalta T, Ozercan R. Evaluation of cervical cytological abnormalities in Turkish population. Indian J Pathol Microbiol. 2012;55:52-5. 
13. Ozgun G, Aydogdu G. Distribution of uterin cervical lesions and relation between age and parity rates in the mardin province. Turk Patoloji Derg. 2013;29:46-50.

14. Waller J, McCaffery K, Wardle J. Beliefs about the risk factors for cervical cancer in a British population sample. Prev Med. 2004; 38:745-53.

15. Baay MF, Verhoeven V, Avonts D, Vermorken JB. Risk factors for cervical cancer development: What do women think? Sex Health. 2004;1:145-9.

16. Giles M, Garland S. A study of women's knowledge regarding human papillomavirus infection, cervical cancer and human papillomavirus vaccines. Aust N Z J Obstet Gynaecol. 2006; 46:311-5.

17. Munoz N, Bosch FX, de Sanjose S, Herrero R, Castellsague X, Shah KV, Snijders PJ, Meijer CJ. Epidemiologic classification of human papillomavirus types associated with cervical cancer. $\mathrm{N}$ Engl J Med. 2003;348: 518-27.

18. Mishra SI, Luce PH, Baquet CR. Increasing pap smear utilization among Samoan women: Results from a community based participatory randomized trial. J Health Care Poor Underserved. 2009;20:85-101.

19. Atalah E, Urteaga C, Rebolledo A, Villegas RA, Medina E, Csendes A. Diet, smoking and reproductive history as risk factor for cervical cancer. Rev Med Chil. 2001;129:597-603.

20. Juneja A, Sehgal A, Mitra AB, Pandey A. A survey on risk factors associated with cervical cancer. Indian J Cancer. 2003;40:15-22.

21. Kjellberg L, Hallmans G, Ahren AM, Johansson R, Bergman F, Wadell G, Angstrom T, Dillner J. Smoking, diet, pregnancy and oral contraceptive use as risk factors for cervical intra-epithelial neoplasia in relation to human papillomavirus infection. Br J Cancer. 2000;82: 1332-8.

22. Jennings-Dozier K, Lawrence D. Sociodemographic predictors of adherence to annual cervical cancer screening in minority women. Cancer Nurs. 2000;23: 350-6.

23. Appleby P, Beral V, Berrington de Gonzalez A, Colin D, Franceschi S, Goodhill A, Green J, Peto J, Plummer M, Sweetland S. Cervical cancer and hormonal contraceptives: Collaborative reanalysis of individual data for 16,573 women with cervical cancer and 35,509 women without cervical cancer from 24 epidemiological studies. Lancet. 2007; 370: 1609-21.

24. Urban M, Banks E, Egger S, Canfell K, O’Connell D, Beral V, Sitas F. Injectable and oral contraceptive use and cancers of the breast, cervix, ovary, and endometrium in black South African women: case-control study. PLoS Med. 2012;9(3):e1001182.

25. Walboomers JM, Jacobs MV, Manos MM, Bosch FX, Kummer JA, Shah KV, Snijders PJ, Peto J, Meijer CJ, Munoz N. Human papillomavirus is a necessary cause of invasive cervical cancer worldwide. J Pathol. 1999;189: 12-9.

26. Sriamporn S, Snijders PJ, Pientong C, Pisani P, Ekalaksananan T, Meijer CJ, Parkin DM. Human papillomavirus and cervical cancer from a prospective study in Khon Kaen, Northeast Thailand. Int J Gynecol Cancer. 2006;16: 266-9.

27. International Collaboration of Epidemiological Studies of Cervical Cancer.Cervical carcinoma and sexual behavior: collaborative reanalysis of individual data on 15,461 women with cervical carcinoma and 29,164 women without cervical carcinoma from 21 epidemiological studies. Cancer Epidemiol Biomarkers Prev. 2009;18: 1060-9.
28. Reiter PL, Katz ML, Ferketich AK, Ruffin MTt, Paskett ED. Measuring cervical cancer risk: Development and validation of the CARE Risky Sexual Behavior Index. Cancer Causes Control. 2009;20: 1865-71.

29. Plummer M, Peto J, Franceschi S. Time since first sexual intercourse and the risk of cervical cancer. Int J Cancer. 2012;130: 2638-44.

30. Curtis KM, Marchbanks PA, Peterson HB. Neoplasia with use of intrauterine devices. Contraception. 2007;75: S60-9.

31. Castellsague X, Diaz M, Vaccarella S, de Sanjose S, Munoz N, Herrero R, Franceschi S, Meijer CJ, Bosch FX. Intrauterine device use, cervical infection with human papillomavirus, and risk of cervical cancer: A pooled analysis of 26 epidemiological studies. Lancet Oncol. 2011;12: 1023-31.

32. Lassise DL, Savitz DA, Hamman RF, Baron AE, Brinton LA, Levines RS. Invasive cervical cancer and intrauterine device use. Int J Epidemiol. 1991;20: 865-70.

33. Sogukpinar N, Saydam BK, Can HO, Hadimli A, Bozkurt OD, Yucel U, Kocak YC, Akmese ZB, Demir D, Ceber E, Ozenturk G. Assessment of cervical cancer risk in women between 15 and 49 years of age: Case of Izmir. Asian Pac J Cancer Prev. 2013;14: 2119-25.

34. Juon HS, Seung-Lee C, Klassen AC. Predictors of regular Pap smears among Korean-American women. Prev Med. 2003;37: $585-92$.

35. Olesen SC, Butterworth P, Jacomb P, Tait RJ. Personal factors influence use of cervical cancer screening services: Epidemiological survey and linked administrative data address the limitations of previous research. BMC Health Serv Res. 2012; $12: 34$

36. Nelson W, Moser RP, Gaffey A, Waldron W. Adherence to cervical cancer screening guidelines for U.S. women aged 25-64: Data from the 2005 Health Information National Trends Survey (HINTS). J Women's Health. 2009;18: 1759-68.

37. Abraido-Lanza AF, Chao MT, Gammon MD. Breast and cervical cancer screening among Latinas and Non-Latina Whites. Am J Public Health. 2004;94: 1393-8.

38. Waller J, Bartoszek M, Marlow L, Wardle J. Barriers to cervical cancer screening attendance in England: A population-based survey. J Med Screen. 2009;16: 199-204.

39. Amankwah E, Ngwakongnwi E, Quan H. Why many visible minority women in Canada do not participate in cervical cancer screening. Ethn Health. 2009;14: 337-49.

40. Sutton S, Rutherford C. Sociodemographic and attitudinal correlates of cervical screening uptake in a national sample of women in Britain. Social Sci Med. 2005;61: 2460-5.

41. Sabates R, Feinstein L.The role of education in the uptake of preventative health care: The case of cervical screening in Britain. Social Sci Med. 2006;62: 2998-3010.

42. Coughlin SS, King J, Richards TB, Ekwueme DU. Cervical cancer screening among women in metropolitan areas of the United States by individual-level and area-based measures of socioeconomic status, 2000-2002. Cancer Epidemiol Biomark Prev. 2006;15: 2154-9.

43. Shanta V, Krishnamurthi S, Gajalakshmi CK, Swaminathan R, Ravichandran K. Epidemiology of cancer of the cervix: Global and national perspective. J Indian Med Assoc. 2000;98: 49-52. 